\title{
PELATIHAN DAN PENDAMPINGAN KEWIRAUSAHAAN, KEUANGAN DAN PEMASARAN BAGI IBU-IBU PENENUN KAIN SASAK DI DESA LENEK KECAMATAN AIKMEL LOMBOK TIMUR
}

\author{
Santi Nururly*), Sulaimiah, Mukmin Suryatni, Emilia Septiani, H. Burhanudin \\ Fakultas Ekonomi Universitas Mataram \\ Jl. Majapahit 62, Mataram 83125, Lombok - Indonesia \\ *alamat korespondensi: snururly@unram.ac.id
}

\begin{abstract}
ABSTRAK
Kain tenun merupakan salah satu budaya nasional yang memiliki keunikan tersendiri yang diajarkan turun temurun, oleh masyarakat Indonesia di semua daerahnya. Pulau Lombok sebagai salah satu tujuan wisata memiliki potensi kain tenun sasak yang masih menggunakan bahan pewarna dari alam. Kegiatan pengabdian kepada masyarakat ini mengangkat potensi kain tenun sasak yang ada di Desa Lenek yang ditenun oleh ibu-ibu di sana. Bagi ibu-ibu dan kaum wanita Desa Lenek, menenun merupakan tradisi, sehingga di setiap rumah rata-rata memiliki hanei, yaitu alat penenun tradisional. produk yang mereka hasilkan belum diproduksi secara maksimal, karena produk tenun yang dihasilkan sebagai tabungan dan digunakan sendiri. Oleh karena itu kegiatan pengabdian kepada masyarakat ini bertujuan untuk memberikan pelatihan kepada ibu-ibu pengrajin tenun mengenai kewirausahaan, memberikan pelatihan desain motif songket, mengenalkan nilai jual ekonomis dari produk yang dihasilkan, pentingnya pemasaran produk dengan menciptakan brand sebagai identitas produk yang dihasilkan dan membuat kemasan kain tenun. Metode Pelaksanaan kegiatan dilakukan dengan ceramah, diskusi, dan praktek pembuatan tenun dengan motif songket. Kegiatan dilaksanakan selama 7 (tujuh) bulan. Kegiatan dilaksanakan di rumah salah seorang penenun di Desa Lenek, Kegiatan pelaksanaan pengabdian kepada masyarakat dapat berjalan lancar, ibu-ibu penenun mengikuti dengan antusias yang tinggi. Keberlanjutan kegiatan ibu-ibu penenun dapat menjadi seorang wirausahawan yang inovatif memproduksi kain tenun sasak lebih beragam coraknya dan berkualitas, sehingga menjadi mandiri dan produktif.
\end{abstract}

10.29303/abdiinsani.v6i1.217

Kata Kunci: Kain Tenun Sasak Lenek, Keuangan, Pemasaran

\section{PENDAHULUAN}

Kain tenun merupakan salah

satu budaya nasional yang memiliki

keunikan tersendiri yang diajarkan turun temurun, oleh masyarakat Indonesia di semua daerahnya. Demikian halnya dengan Pulau Lombok sebagai salah satu tujuan wisata 
memiliki daerah yang memiliki potensi kain tenun, seperti Sukarare di Lombok Tengah dan Pringgesela di Lombok Timur (anonymous, 2018). Hal ini karena Pringgasela yang paling gencar mempromosikan produk tenun. Selain itu masyarakat Pringgasela menjadikan bisnis kain tenun sebagai mata pencaharian utama, dan merekapun membuat art shop. Produk yang dijual di sana ternyata tidak saja berasal dari daerah tersebut tetapi juga berasal tetangganya Desa Lenek Lauk, Kecamatan Aikmel.

Di Desa Lenek Lauk kondisinya berbeda dengan Pringgasela, dimana produk kain sasak yang dihasilkan penenun hanya sebagai usaha sambilan. Mereka menenun sekedar aktivitas sampingan, dan menenun bagi mereka untuk melestarikan tradisi nenek moyang, Kain tenun yang dihasilkan di simpan sebagai tabungan. Jika mereka butuhkan baru dijual. Inilah yang menyebabkan pedagang dari Pringgasela yang membeli produk mereka, sehingga produk lenek tidak dikenal. Padahal merk/brand penting bagi produsen untuk dapat diingat produknya oleh konsumen.
Sebagian besar penduduk di Desa Lenek Lauk perempuan, karena kaum lelakinya mencari kehidupan sebagai tenaga kerja ke luar negeri. Para wanita di setiap rumah di Desa Lenek memiliki alat tenun,.Para wanita di Desa Lenek melakukan aktivitas menenun dilakukan sejak mereka menamatkan sekolah dasar. Kegiatan menenun bisa dikatakan sebagai kegiatan kerajinan. Oleh karena itu produk kain sasak dari Lenek memiliki potensi untuk dikembangkan.

Penenun melakukan menenun dengan menggunakan alat pintal yang sangat sederhana (tradisional) yang disebut Gedogan. Motif tenun sasak daerah Lenek masih terbatas. Rata-rata penenun mengandalkan tenaga manusia, sehingga waktu yang digunakan untuk penyelesaian satu kain tenun selama 3 (tiga) minggu sampai 1 bulan.

Keunikan kain tenun Lenek karena menggunakan bahan dari alam, demikian juga dengan pewarnaan memakai warna dari alam Namun saat ini benang sebagai bahan dasar tenunan, sebagian besar dibeli dekat tempat tinggal dan berasal dari 
Surabaya. Untuk pewarnaan berasal dari bahan alami yang berasal dari tanaman di sekitar tempat tinggal mereka. Dalam kualitas produk, menurut Kotler (2008) menyatakan bahwa jika pemasar memperhatikan kualitas, bahkan diperkuat dengan periklanan dan harga yang wajar maka konsumen tidak akan berpikir panjang untuk melakukan pembelian terhadap produk.

Oleh karena itu harga merupakan salah satu variabel penting dalam pemasaran, dimana harga dapat mempengaruhi konsumen mengambil keputusan untuk membeli suatu produk (Kotler, 2008). Harga produk tenun sasak, rata-rata setiap lembar tenun berukuran $4.5 \mathrm{~m} \times 60 \mathrm{~cm}$, dengan beragam motif seperti masrais, dan polos. Dari sisi harga kain tenun yang berasal dari pewarnaan alami dan menggunakan jenis benang yang berkualitas seharga Rp. $600.000-R p$ 1.000.000, sedangkan menggunakan benang dan pewarnaan sintetis seharga Rp 250.000 - Rp. 300,000 per satuan lembar tenun

Fenomena yang dapat dilihat dari para wanita penenun di Desa
Lenek bahwa menenun bukan merupakan sumber penghasilan utama hanya sebagai tabungan, dan mereka melakukan tenun hanya merupakan aktivitas selingan, padahal jika dikelola dengan baik ini merupakan potensi yang perlu dikembangkan dan dapat menghasilkan pendapatan dan mensejahterakan mereka.

Upaya pemerintah untuk meningkatkan pertumbuhan ekonomi harus didukung diperkuat dengan masyarakat yang mandiri secara ekonomi. Oleh karena itu potensi warga desa Lenek Lauk terutama bagi ibu-ibu penenun di sana perlu diberikan inisiasi wirausaha sehingga potensi yang mereka miliki dengan budaya membuat tenun bisa memberikan penghasilan yang baik untuk meningkatkan kesejahteraan hidup mereka. Oleh karena itu tim pengabdian melihat perlunya pelatihan tentang kewirausahaan untuk menumbuhkan jiwa kewirausahaan dan belajar beragam motif tenun sasak untuk memperkaya produk yang dihasilkan, bagaimana mengelola keuangan serta pemasaran guna mengembangkan usaha tenun sasak, 
yang harapannya dapat meningkatkan kesejahteraan para penenun.

Tujuan dari kegiatan pengabdian kepada masyarakat ini adalah sebagai berikut:

1. Memberikan pelatihan kepada ibuibu pengrajin tenun mengenai kewirausahaan

2. Memberikan pelatihan tentang cara menenun songket untuk memperkaya motif tenun sasak yang dihasilkan

3. Memberikan pelatihan tentang pentingnya menghitung nilai jual ekonomis dari produk yang dihasilkan

4. Memberikan penyuluhan tentang Pentingnya memiliki merk/branding dari produk tenun yang dihasilkan sebagai identitas produk yang dihasilkan

5. Memberikan penyuluhan tentang pentingnya pemasaran produk dengan membuat kemasan produk yang dihasilkan

Manfaat yang diharapkan dari pelaksanaan kegiatan pengabdian kepada masyarakat adalah sebagai berikut: a. Menggugah jiwa kewirausahaan para penenun kasin sasak

b. Mendapat ilmu ragam motif songket yang belum pernah mereka ketahui

c. Memberikan pelatihan tentang pentingnya menghitung nilai ekonomis dari produk yang dihasilkan

d. Untuk memasarkan produk dengan merk/branding sendiri

\section{METODE KEGIATAN}

Kegiatan pengabdian kepada masyarakat dilaksanakan selama 6 (enam) bulan dari bulan April sampai dengan bulan Oktober 2018 di Desa Lenek Kecamatan Aikmel Kabupaten Lombok Timur. Metode pendekatan yang digunakan dalam kegiatan ini adalah partisipatif, yaitu metode pendekatan yang berorientasi pada upaya peran serta ibu-ibu penenun secara langsung untuk ikut serta dalam proses kegiatan pelatihan, mulai dari perencanaan, pelaksanaan dan evaluasi. Kegiatan diisi dengan ceramah, diskusi, dan praktek menenun motif songket. Tim Pengabdian kepada masyarakat 
sebagai fasilitator dan motivator untuk keberhasilan kegiatan.

Permasalahan yang ditemui dilokasi antara lain:

1. Tingkat Pendidikan para penenun masih rendah, rata-rata tamat SD

2. Budaya penenun menghasilkan kain tenun hanya sebagai selingan dikala senggang.

3. Belum terfikir mereka untuk menghitung betapa besarnya nilai ekonomis produk yang dihasilkan.

4. Produk tenun yang dihasilkan memiliki desain yang terbatas

5. Sifat menerima keadaan

6. Belum adanya merk/branding dan kemasan sebagai identitas produk yang dijual

7. Kegiatan memasarkan hasil tenun belum gencar dilakukan, cendeung menunggu pembeli.

Untuk memecahkan masalah yang dihadapi, kegiatan yang ditawarkan sebagai berikut :

1. Memberikan pelatihan tentang bagaimana menjadi wirausahawan

2. Memberikan pelatihan ragam motif songket
3. Memberikan pelatihan tentang perhitungan harga jual ekonomis tenun yang dihasilkan

4. Memberikan pelatihan pemasaran tentang pentingnya merk/branding bagi suatu usaha

5. Memberikan pelatihan pemasaran tentang pentingnya desain dan kemasan atas produk yang dihasilkan

\section{HASIL DAN PEMBAHASAN}

Sasaran dilaksanakan kegiatan ditujukan kepada ibu-ibu penenun kain sasak di Desa Lenek. Rata-rata ibuibunya dan remaja putri semuanya dapat menenun, dan memiliki alat tenun. Kepada merekalah pelatihan diberikan sehingga mereka dapat menjadi wirausaha yang handal dengan dibekali oleh pengetahuan tentang wirausaha, beragam jenis motif produk, bagaimana menentukan nilai jual, dan pemasaran dengan strategi merk/branding dan desain kemasan.

\section{Tahap Persiapan}

$$
\text { Kegiatan diawali dengan }
$$

koordinasi antara Tim pengabdian dengan wakil dari ibu-ibu di Desa Lenek yaitu ibu Fathiah dan Ibu Sugiati untuk menentukan waktu, dan rencana 44

Available online : http://abdiinsani.unram.ac.id 
kegiatan pelatihan bahan materi yang akan digunakan dalam pelatihan, menentukan jumlah peserta pelatihan, mencari pelatih dan kesiapan tempat pelatihan.

Selanjutnya ditentukan jumlah peserta pelatihan 15 - 20 orang, dengan asumsi agar kelompok tidak terlalu besar sehingga metode pembelajaran dapat tercapai.

Kegiatan pelatihan akan diisi oleh Tim Pengabdian dan Pelatih Tenun songket yang berasal dari Praya yaitu Ibu Saifah Sukmawati dan Ibu Jelita.

\section{Tahap Pelaksanaan Kegiatan}

Kegiatan pelatihan dilakukan dalam beberapa tahap, yaitu:

a. Tahap pertama dilaksanakan pada tanggal 25 September 2018 diisi dengan kegiatan ceramah, dan diskusi meliputi kegiatan pengajaran tentang kewirausahaan, keuangan dan pemasaran.

Materi yang disampaikan pada kegiatan pelatihan :

- Bagaimana menumbuhkan jiwa wirausaha

- Kiat sukses menjadi pengusaha
- Pentingnya melakukan penentuan harga jual

- Pentingnya merk/branding bagi usaha

- Pentingnya kemasan dalam memproduksi

b. Tahap kedua dengan praktek pembuatan tenun songket dibimbing oleh Ibu Saifah Sukmawati dan Jelita yang berasal dari Lombok Tengah selama 3 (tiga) hari, yaitu dari tanggal 26 September sd 28 September 2018.

Ciri khas produk tenun sasak lenek memiliki motif khas daerah dengan menggunakan pewarnaan alami dan sintetis. 


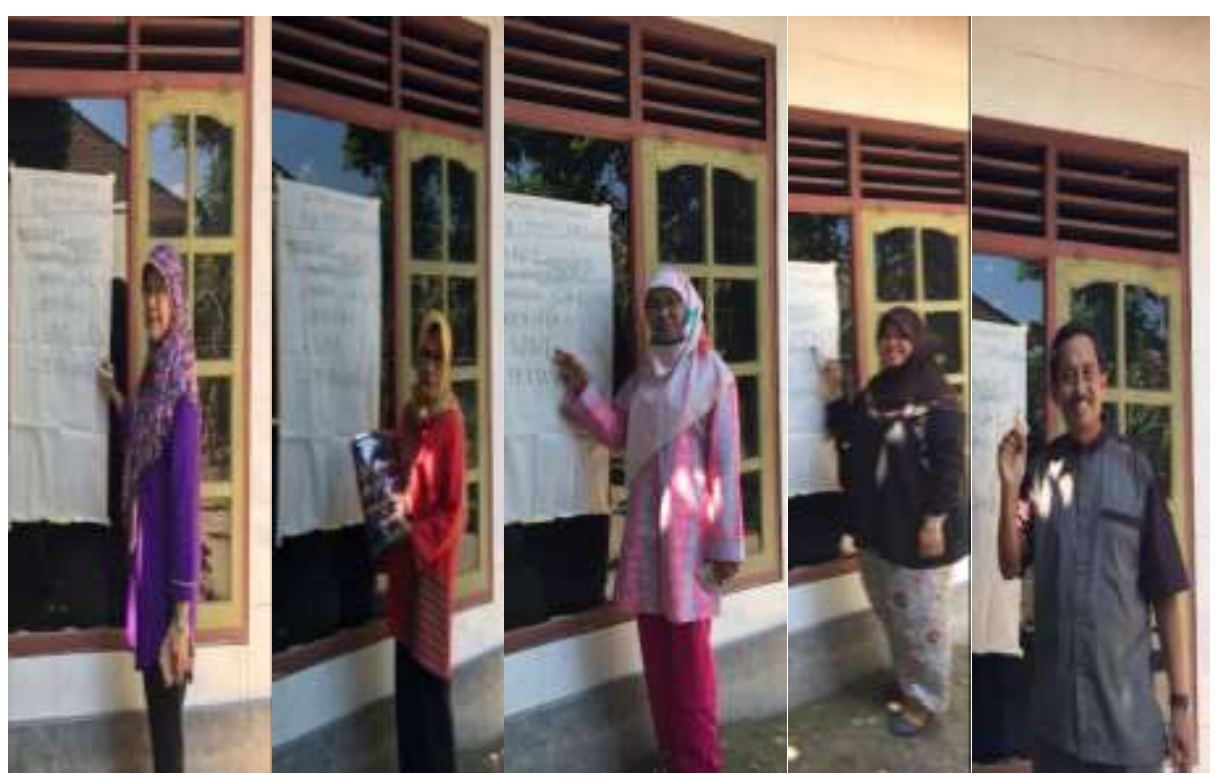

Gambar 1. Tim Kegiatan pengabdian kepada masyarakat memberikan materi pada kegiatan pelatihan

Ukuran kain yang dihasilkan umumnya berukuran $4.5 \mathrm{~m} \times 60 \mathrm{~cm}$. Proses menenun yang dilakukan oleh para pengajin sudah menggunakan benang yang siap pakai tinggal di klos atau digulung. Untuk pembuatan kain tenun dengan pewarnaan sintetis mudah di dapat karena telah ada toko yang menjual di dekat mereka tinggal. Benang tersebut berasal dari Surabaya. Namun untuk menghasilkan kain santinurulytenun dengan pewarnaan alami yang berasal dari alam mereka perlu cari bahan dasar dan mengolahnya sendiri.

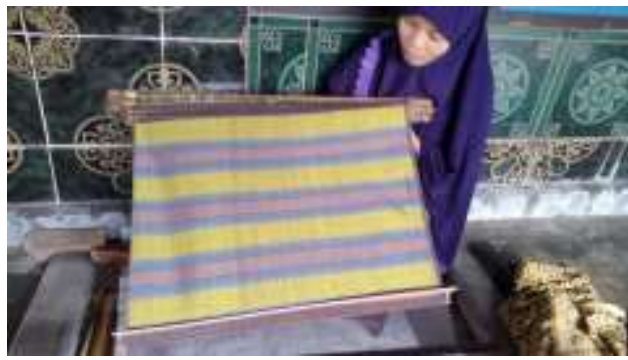

Gambar 2. Tenun khas Desa Lenek Lauk dari pewarnaan alami

Poses pewarnaan yang dilakukan oleh para pengrajin, yaitu dengan menggunakan daun tarum atau menggunakan kulit kayu dan beberapa bahan yng bisa menimbukan warna sesuai dengan kebutuhan..

Sehingga mereka perlu memiliki inovasi dalam proses pewarnaan ini. Mereka butuh informasi untuk mengetahui beragam warna dari bahan alam. 
Dalam kegiatan ini pelatih memperkenalkan cara menenun songket gaya khas Lombok tengah yang telah dikenal dengan ragamnya, sehingga ibu-ibu di Lenek dapat pengetahuan tentang ragam motif lain untuk menambah kreativitas mereka.

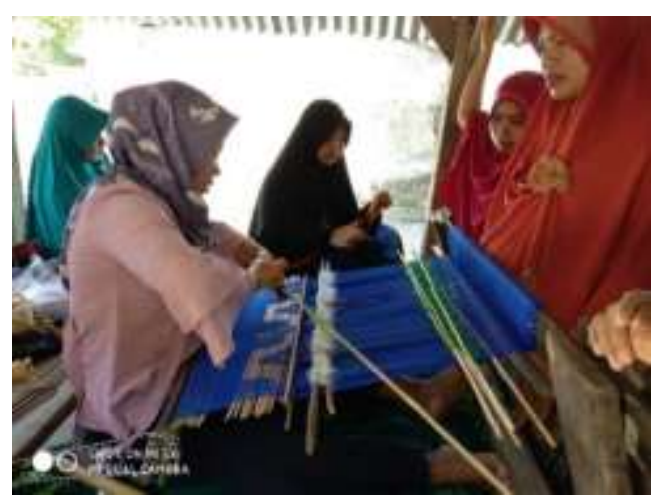

Gambar 3. Pelatihan membuat Tenun Songket

Tahap tiga meliputi pendampingan kepada ibu-ibu untuk mau mencoba berlatih membuat kain tenun sasak bermotif songket. Waktu pendampingan pembuatan songket selama 2 minggu dengan target jadi produk tanggal 20 Oktober 2018. Gambar 4. menunjukkan Tenun songket hasil pembelajaran

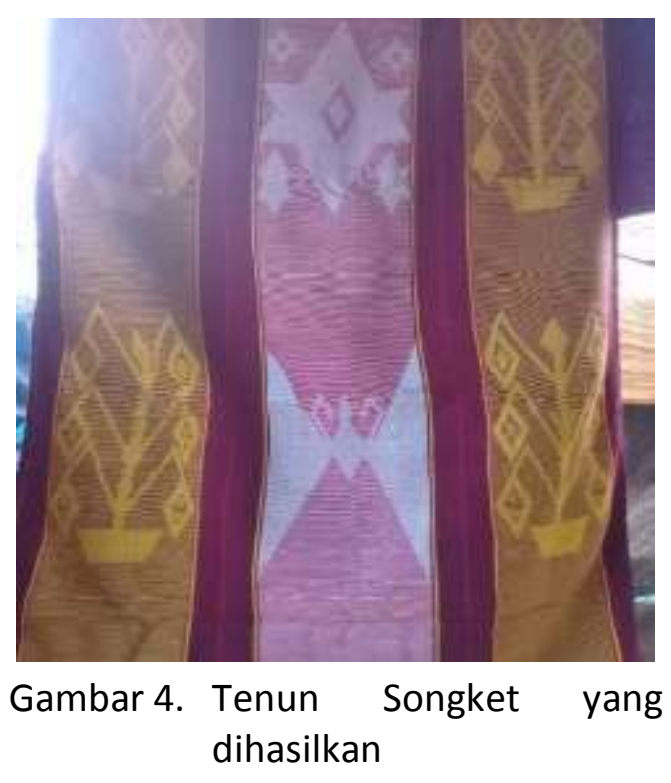

Dari hasil pembelajaran mengenai pembuatan desain dan brand dari produk tenun yang dihasilkan, dibuatlah produk tenun dengan kemasan yang siap dipasarkan.

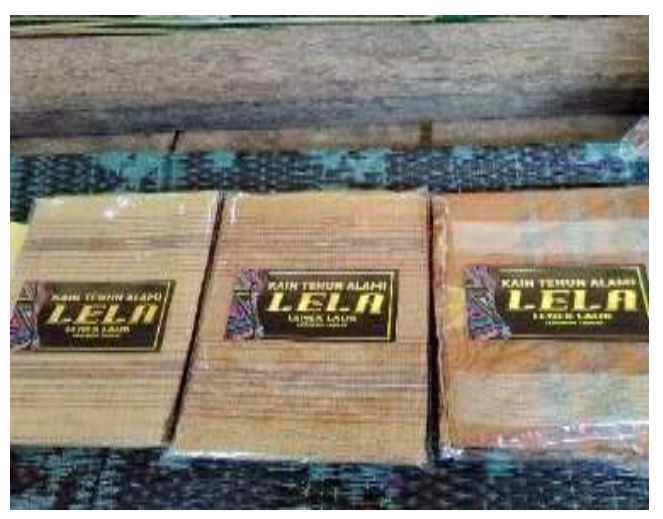

Gambar 5. Produk tenun diberi kemasan dan label

Pentingnya brand atau merk agar para pembeli dapat mudah mendapatkan produk, maka dibuat plang nama Art Shop Lela yang merupakan kepanjangan dari Lenek Lauk. 


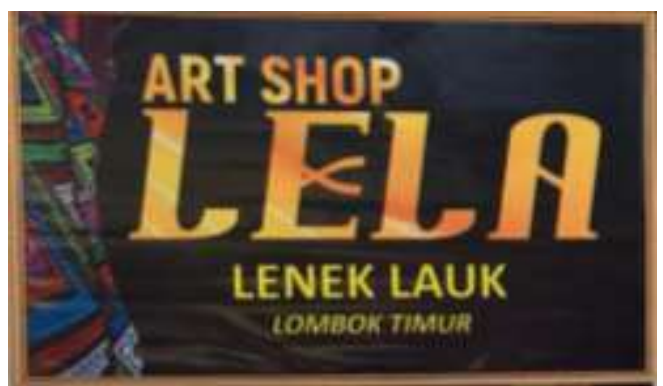

Gambar 6. Plang nama LELA

\section{Tahap Evaluasi}

Kegiatan evaluasi, dilakukan pada tanggal 20 Oktober 2018. Keberhasilan kegiatan pengabdian kepada masyarakat ini diukur dari antusiasme dari ibu-ibu penenun dalam menerima pelatihan, dan pembelajaran, serta telah dihasilkan produk tenun songket khas lenek .

\section{KESIMPULAN DAN SARAN}

\section{Kesimpulan}

Melalui kegitan pelatihan ini ibu-ibu di Desa Lenek terbuka pandangan untuk merubah pola pikir bahwa produk tenun sasak sebagai tabungan di rubah menjadi produk yang bernilai ekonomis yang dapat diproduksi setiap saat dan dijadikan mata pencaharian, oleh karena itu merubah pola pikir ibu rumah tangga menjadi wirausaha. Untuk mendukung hal tersebut telah diberikan pengetahuan tentang keuangan menentukan harga jual, dan pemasaran dengan mengenalkan pentingnya merk/branding dan perlunya kemasan untuk menunjukkan identitas produk yang dihasilkan. Diharapkan mereka ke depannya akan terus berlatih untuk mengembangkan produk dari sisi jumlah dan kualitas guna meningkatkan produktivitas yang pada akhirnya meningkatkan kesejahteraan hidup mandiri.

\section{Saran}

1. Untuk meningkatkan nilai jual dari produk tenun sasak, maka perlu terus kreativitas dari ibu-ibu penenun untuk berkreasi dalam mencari ragam motif produknya, disamping tetap mempertahankan motif tradisional.

2. Ke depan kegiatan pengabdian kepada masyarakat perlu memberikan pelatihan dan pendampingan dengan memanfaatkan teknologi untuk peningkatan produktivitas dan keuntungan usaha. 


\section{UCAPAN TERIMA KASIH}

Tim kegiatan pengabdian kepada masyarakat mengucapkan terima kasih kepada Lembaga Penelitian dan Pengabdian Pada Masyarakat (LPPM) Universitas Mataram, dan semua unsur yang ikut serta dalam mendukung terlaksananya kegiatan pengabdian kepada masyarakat ini sehingga kegiatan dapat berjalan dengan baik.

\section{DAFTAR PUSTAKA}

Anonimous, 2018. Profil Sukses Pengusaha yang Melestarian
Tenun

Tradisional. https/bisnisukm.com/profilsukses-pengusaha-yangmelestarikan-tenuntradisional.html. Diakses : 19 Maret 2018

Hoeffler, Steve., Keller, Kevin Lane. 2003.The Marketing Advantages of Strong Brands, Brand Management, Vol. 10, No.6

Kotler, Philip. 2008. Prinsip-prinsip Pemasaran. Jakarta: Erlangga

Stanton, William, J 1994. Fundamental of Marketing. Thenth ed. McGraw Hill Inc; Singapore. http://www.akar-media.com/kaintanun-pringgasela-lomboktimur_akarmedia_majalah-online. Diakses 03 Maret 2018 